\title{
P324: Management of risk in a country in crisis: hepatonephritis cases related to artemisinin- based combinations therapy
}

\author{
T Daubrey Potey*, M Kamagaté, H Dié-Kacou \\ From 2nd International Conference on Prevention and Infection Control (ICPIC 2013) \\ Geneva, Switzerland. 25-28 June 2013
}

\section{Objectives}

To analyze risk management when occurred hepatonephritis cases related to Artemisinin-based Combinations Therapy.

\section{Methods}

A technical committee of management of hepatonephritis cases has been set up by the health ministry. The terms of references were: 1 ) state of knowledges on the subject from the pharmacovigilance database of Côte-d'Ivoire; 2) Carrying out of an investigation in public and private hospitals; 3 ) start -up a plan of communication for the health professionals and population.

\section{Results}

States of knowledges: for 10 years, serious Adverse Drug reactions have been notified (57\%), like black fever, hepatonephritis and serious hepatitis cases related to any antimalarial monotherapies : amodiaquin, artemisinin derivatives and quinine. Retrospective study: we collected 100 files. The principal damage was hepatic (63\%), hepatorenal (26\%) and hematologic (19\%). Antimalarial drugs implicated were: quinine $(30,4 \%)$, artemether-lumefantine $(21,4 \%)$ and artesunate-sulfamethopyrazine $(13,6 \%)$. Prospective study: We have analyzed 25 cases over 3 months of investigation.

\section{Conclusion}

Start-up of a plan of communication: we drafted and sent an alarm note and recommendations of good use of antimarial combinotherapies to prescribers and dispensers.

UFR des Sciences pharmaceutiques, Université Felix Houphouët Boigny, Abidjan, Côte d'Ivoire

\section{BioMed Central}

\section{Disclosure of interest}

None declared.

Published: 20 June 2013

doi:10.1186/2047-2994-2-S1-P324

Cite this article as: Daubrey Potey et al.: P324: Management of risk in a country in crisis: hepatonephritis cases related to artemisinin- based combinations therapy. Antimicrobial Resistance and Infection Control 2013 2(Suppl 1):P324.
Submit your next manuscript to BioMed Central and take full advantage of:

- Convenient online submission

- Thorough peer review

- No space constraints or color figure charges

- Immediate publication on acceptance

- Inclusion in PubMed, CAS, Scopus and Google Scholar

- Research which is freely available for redistribution
() Biomed Central 